part $S 3.7 \mathrm{~km} . / \mathrm{sec}$; (4) lower layer dunite with base uncertain, velocity of $P 7 \cdot 8$ (?) $\mathrm{km} . / \mathrm{sec}$. and $S 4.4 \mathrm{~km}$./sec. This varies somewhat from the European structure, chiefly in having a thinner granitic layer and a thicker intermediate layer than Europe. The phase $P_{6 \cdot 0}$ may correspond to the phase $P_{Y}$ in California, and it is suggested that there may be some resemblance between the crustal structures of New Zealand and Japan.

\section{PLANTS USEFUL AND ORNAMENTAL}

$\mathrm{U}^{\mathrm{N}}$

NLESS he be a professed systematist, the modern botanist, newly arrived in the tropics, as also the horticulturist and agriculturist, may well find himself bewildered and dismayed, as well as bewitched, by the diversity and profusion of the vegetable forms which everywhere greet the eye. Those first encounters, indeed, provide a pleasure not entirely devoid of pain; they force a realization of the small knowledge that one so often brings to a vast subject. Such local works as afford simple and direct guidance in the identification of the more common genera and species are therefore of great value and should be appreciated accordingly.

In this category is the volume just issued by R. $O$. Williams and R. O. Williams, jun. ("The Useful and Ornamental Plants of Trinidad and Tobago", third edition, Government Printers, Trinidad), the original edition having been published by W. G. Freeman and R. O. Williams in 1927 and a second in 1928. The object, in the first instance, was to give information about native and introduced plants possessing interest because of their useful and ornamental qualities. Actually, a brief random sampling shows that the title errs on the side of modesty, for many plants, not essentially useful or ornamental, but of considerable botanical interest, are also described - a feature not only desirable in itself but also one which lends a fullness to the work.

The Colony, as the authors state, possesses many wild plants, prized for their economic or decorative value; and many plants have been successfully introduced from all parts of the world. "To obtain information on many of these is often difficult, even in a well appointed botanical library, entailing search through various standard works of reference, and often the agricultural, botanical and other publications of several other countries. To the person not so equipped the task is frequently a hopeless one." Thus appreciating the noed, the authors have successfully fulfilled their task. In this edition the lists of useful plants have been completely rearranged and keys have been provided to facilitate identifications. Cultural notes make a useful addition to plant descriptions and notes on crop plants have been brought up to date.

It is a pleasant occupation to make an excursion at random through such a work, where East meets West and where the denizen of the high woods comes to rest by the side of more everyday garden staples, but for the botanist the features of greatest interest are perhaps those sections where orchids, ferns, grasses, cycads, conifers, cacti and mangroves are treated as groups. At a glance the wealth of the Islands can be seen. Further, what is true of the major groups is true of the flora as a whole; the number of native and introduced plants possessing particular interest is surprising.

\section{FORTHCOMING EVENTS}

\author{
Thursday, June 5
}

Royal Society of Medicine (at 1 Wimpole Street, London, W.1) at 5.30 p.m.-Prof. Julian Huxley, F.R.S. : "Art as a Social Function" (Lloyd Roberts Lecture).

Chemical Society, Institute of Chemistry, and Society of Chemical Industry (Joint Meeting in the University Chemical Department, Bristol) at 6.30 p.m. -Prof. G. M. Bennett : "Liquid Crystals".

\section{APPOINTMENTS VACANT}

Lecturer in Mechanical Engineering-The Principal, Aston Technical College, Whitehead Road, Birmingham 6 (June 7 )

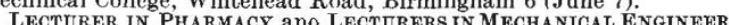
LECTURER IN PHARMACY ANO LECTURERS IN MECHANICAL ENGINEER Birmingham 1 (June 7 )

SENIOR LECTCRER IN THE DEPARTMENT OF ELECTRICAL ENGINEERING-The Principal, Heriot-Watt College, Edinburgh (June 9).

\section{REPORTS AND OTHER PUBLICATIONS}

\author{
(not included in the monthly Books Supplement)
}

Great Britain and Ireland Annual Report of the Oundle School Natural History Society. Pp.
20. (Oundle: Oundle School.)

Scientifle Proceedings of the Royal Dublin Society. Vol. 22 (N.S.) No. 38: The Vitamin D Requirements of the Growing Pig. By Brendan J. Senior. Pp. 379-386. 6d. Vol. 22 (N.S.), No. 39 : Studie on the Oxidising Action of Selenious Acid. 1: Organic Sulphu Compounds. By A. E. A. Werner. Pp. 387-392. 6d. (Dublin : Hodges, Catalogue of 20,554 Faint Stars in the Cape Astrographic Zone $-40^{\circ}$ to $-52^{\circ}$ for the Equinox of $1900^{\circ} 0$ giving Positions, Precessions, Proper Motions and Photographic Magnitudes derived from Photographs taken at the Royal Observatory, Cape of Good Hope, under the direction of Dr. H. Spencer Jones and Dr. J. Jackson; also Spectral Types classifled from Plates at the Harvard College Observatory, Cambridge, Mass., U.S.A., by Miss Annie J. Cannon. Pp. lvii 414. (London: H.M. Stationery Office.) 42s. net.

Observations made at the Royal Observatory, Greenwich, in the Year 1936, in Astronomy, Magnetism and Meteorolony, under the Year 1936, in Astronomy, Magnetism and Meteorology, under the direction of Dr. H. Spencer Jones. Pp. vii +A $78+$ B16 + Cix $+161+$ Reports on Progress in Physics. Vol. 7 (1940). General Editor: J. H. Awbery. Pp. iii +362. (London: Physical Society). 228. 6d. net.

\section{Other Countries}

Annals of the Carnegie Museum. Vol. 28, Art. 12: A New Crocodilian, Hassiacosuchus kayi from the Bridger Eocene Beds of Wyoming. By Charles C. Mook. Pp. 207-220 + plates 23-25. (Pittsburgh, Pa.: Carnegie Museum.)

Smithsonian Miscellaneous Collections. Vol. 99, No. 21: A New Shipworm from Panama. By Paul Bartsch. (Publication 3632.) Pp. ii $+2+1$ plate. (Washington, D.C.: Smithsonian Institution.)

Smithsonian Institution. Explorations and Field-Work of the Smithsonian Institution in 1940 . (Publication 3631.) Pp. v +100 . (Washington, D.C. : Smithsonian Institution.)

Annual Report of the Director of the Japan Institute for Science of Labour for 1939. By Dr. G. Teruoka. Pp. ii 14. (Tokyo: Japan Institute for Science of Labour.)
[85 United States Department of the Interior: Fish and Wildlife Service. Wildlife Circular 6: The House Rat. By James Silver. Pp. iv +18 . (Washing'on, D.C.: Government Printing Office.) 5 cents.

University of Bombay: Department of Chemical Technology. Annual Report 1939-40. Pp. 28. (Bombay: The University.) [95 Imperial Councii of Agricultural Research. Scientifle Monograph
No. 14: Further Studies on Cereal Rusts in India. By Dr. K. C. Mehta. Pp. vii $+224+12$ plates. (Delhi: Manager of Publications.) Mehta. Pp. vii $+224+12$ plates. (Delhi: Manager of Publications.)
6 rupees ; 98. $6 d$. 6 rupees; $98.6 d$. Stratigraphy of South Singhbaum. By Dr. J. A. Dunn. Pp. iv $+303-$ $370+$ ix + plates $33-37$. (Calcutta : Geological Survey of India.) 1.14 rupees; $28.9 d$.

Publications of the Observatory of the University of Michigan. Vol. 8, No. 5: The Spectrum of Nova Cygni III (1920). By Ralph B. Baldwin. Pp, 61-94+2 plates, Vol. 8, No. 6: The Francis C. McMath Memorial 24-inch Reflecting Telescope of the McMath-Hulbert Observatory. By Robert R. McMath. Pp. 95-102+6 plates. Vol. 8, No. 7 : Dimensions and Shape of the Andromeda Nebula. By Robley $\mathrm{C}$. Wiliams and W Albert Hiltner. $\mathrm{Pp}$ 103-106+1 plate. Mich. : University of Michigan.) 